Article

\title{
Exploring the Biochemical Origin of DNA Sequence Variation in Barley Plants Regenerated via in Vitro Anther Culture
}

\author{
Piotr T. Bednarek ${ }^{1, *}$, Jacek Zebrowski ${ }^{2}$ (D) and Renata Orłowska ${ }^{1}$ (D) \\ 1 Department of Plant Physiology and Biochemistry, Plant Breeding and Acclimatization Institute-National \\ Research Institute, Radzików, 05-870 Błonie, Poland; r.orlowska@ihar.edu.pl \\ 2 Institute of Biology and Biotechnology, University of Rzeszow, Al. Rejtana 16c A, 35-959 Rzeszow, Poland; \\ jaze28@interia.pl \\ * Correspondence: p.bednarek@ihar.edu.pl; Tel.: +48-22-7334533
}

Received: 22 June 2020; Accepted: 10 August 2020; Published: 11 August 2020

\begin{abstract}
Tissue culture is an essential tool for the regeneration of uniform plant material. However, tissue culture conditions can be a source of abiotic stress for plants, leading to changes in the DNA sequence and methylation patterns. Despite the growing evidence on biochemical processes affected by abiotic stresses, how these altered biochemical processes affect DNA sequence and methylation patterns remains largely unknown. In this study, the methylation-sensitive Amplified Fragment Length Polymorphism (metAFLP) approach was used to investigate de novo methylation, demethylation, and sequence variation in barley regenerants derived by anther culture. Additionally, we used Attenuated Total Reflectance Fourier Transform Infrared (ATR-FTIR) spectroscopy to identify the spectral features of regenerants, which were then analyzed by mediation analysis. The infrared spectrum ranges (710-690 and 1010-940 $\mathrm{cm}^{-1}$ ) identified as significant in the mediation analysis were most likely related to $\beta$-glucans, cellulose, and S-adenosyl-L-methionine (SAM). Additionally, the identified compounds participated as predictors in moderated mediation analysis, explaining the role of demethylation of CHG sites (CHG_DMV) in in vitro tissue culture-induced sequence variation, depending on the duration of tissue culture. The data demonstrate that ATR-FTIR spectroscopy is a useful tool for studying the biochemical compounds that may affect DNA methylation patterns and sequence variation, if combined with quantitative characteristics determined using metAFLP molecular markers and mediation analysis. The role of $\beta$-glucans, cellulose, and SAM in DNA methylation, and in cell wall, mitochondria, and signaling, are discussed to highlight the putative cellular mechanisms involved in sequence variation.
\end{abstract}

Keywords: ATR-FTIR spectroscopy; $\beta$-glucans; cellulose; DNA demethylation; S-adenosyl L-methionine; sequence variation; time of in vitro culture

\section{Introduction}

It is commonly believed that sequence variation during in vitro tissue culture is either caused by the activation of transposons [1], resulting in DNA demethylation [2] during cell reprogramming [3], or by the presence of modified cytosines [4], which undergo further modifications [5] but escape DNA repair mechanisms [6]. DNA demethylation is a widely used epigenetic marker in plants. DNA demethylation occurs in two sequence contexts: symmetric and asymmetric [7]. Symmetric DNA demethylation affects CG and CHG sequences (where $\mathrm{H}=\mathrm{A}, \mathrm{T}$, and $\mathrm{C}$ ) predominantly in gene-rich euchromatic regions, whereas asymmetric DNA demethylation affects $\mathrm{CHH}$ sequences mostly in heterochromatic regions. The maintenance of both types of DNA methylation patterns is regulated by distinct mechanisms [7]. 
Two mechanisms of DNA demethylation have been identified: passive and active. The passive mechanism assumes that DNA loses epigenetic marks during replication in the absence of the methylation of newly synthesized DNA strands by DNA (cytosine-5)-methyltransferase 1 (DNMT1), an enzyme that catalyzes the transfer of methyl groups to specific CpG sites during replication [8]. DNMT1 is responsible for the maintenance of DNA methylation patterns during replication. Passive demethylation has been reported in the male gametophyte and endosperm with reduced RNA-directed DNA methylation (RdDM) factors [9].

Active DNA demethylation utilizes 5-methylcytosine (5 mC) DNA glycosylases [10] and is a distinct feature of the maternal central cell. DEMETER-LIKE 2 (DML2) and DML3 function in nonsomatic and somatic tissues [11], and delete the methylated cytosines via the base excision repair (BER) pathway $[12,13]$. Active DNA demethylation depends on the REPRESSOR OF SILENCING 1 (ROS1) family, which comprises of $5 \mathrm{mC}$ DNA glycosylases and apurinic/apyrimidinic lyases that antagonize de novo DNA methylation via the RdDM pathway to prevent DNA hypermethylation. ROS1 counteracts de novo DNA methylation in transgenes by actively promoting DNA demethylation. Other enzymes such as DEMETER (DME), DML2, and DML3 also participate in this process. DME regulates gene imprinting [14,15], whereas DML2 and DML3 are involved in the proper distribution of DNA methylation marks [13]. Recent studies show that active DNA demethylation is mediated by the increased DNA methylation (IDM) complex. Moreover, de novo DNA methylation and demethylation are under the control of a methylation-sensing genetic element [8]. In Arabidopsis thaliana, both de novo DNA methylation and demethylation processes are required for cellular reprogramming during in vitro tissue culture [16].

In active DNA demethylation, DNA glycosylases remove $5 \mathrm{mC}$ and cleave the $\mathrm{N}$-glycosidic (base-sugar) bond, generating apurinic or apyrimidinic sites, followed by gap-filling by a DNA polymerase and a DNA ligase [17]. In addition to the BER pathway, DNA demethylation is also accomplished by the removal of a DNA fragment, and the gap is filled using new nucleotides via the nucleotide excision (NER) or mismatch repair (MMR) mechanism. The NER and MMR mechanisms rely on the removal of $5 \mathrm{mC}$ by further modifications such as oxidation of the methyl group, leading to the formation of 5-hydroxymethylcytosine $(5 \mathrm{hmC})[5,18]$. In active DNA demethylation, deamination of $5 \mathrm{mC}$ generates thymine ( $\mathrm{T}$ ), which may result in $\mathrm{C} \rightarrow \mathrm{T}$ transition, as $\mathrm{T}$ is not recognized by the uracil-DNA glycosylase. Thus, mutations due to deamination are the most frequent, as they escape the cell repair system. Alternatively, oxidation of $5 \mathrm{mC}$ may also contribute to sequence variation [19].

Recent studies demonstrate that abiotic stress conditions are responsible for DNA methylation-dependent stress memory in plants [20]. In some cases, changes in DNA methylation patterns are associated with plant stress responses [21]. Furthermore, abiotic stresses such as cold and drought are responsible for changes in DNA methylation patterns [22]. Additionally, studies on plant responses to in vitro tissue culture-induced stress show that tissue culture conditions promote changes in stress-induced DNA methylation and/or demethylation patterns [23-27]. Machczyńska and colleagues reported a relatively high level of DNA sequence variation between the donor plant and its regenerants [28]. However, evidence supporting a direct link between DNA demethylation/sequence variation and in vitro tissue culture conditions is lacking.

Sequence variation induced by in vitro tissue culture has been investigated using the methylation-sensitive Amplified Fragment Length Polymorphism (metAFLP) approach [28,29], which provides quantitative information about the DNA sequence. Furthermore, Attenuated Total Reflectance Fourier Transform Infrared (ATR-FTIR) spectroscopy has been used to analyze the extent to which nucleotide variation affects biochemical compounds in plants regenerated by an in vitro culture [30]. ATR-FTIR spectroscopy is a powerful technique that has been widely used to analyze the biochemical profiles of diverse biological materials, including plant tissues [31,32]. ATR-FTIR spectroscopy is a fast and simple measurement procedure that does not require special sample preparation, thus allowing the examination of a large number of samples. Although ATR-FTIR spectroscopy is not similarly precise in quantitative analysis of a specific analyte like time-consuming 
chromatography, it does allow for comprehensive survey of all essential compounds present in the material under investigation on the basis of a single short-time measurement. ATR-FTIR spectroscopy is generally used in combination with various mathematical and statistical tools that enhance its research potential, e.g., to discriminate between samples according to taxonomic categories $[33,34]$ or to determine susceptibility to stresses [35-37]. Additionally, mediation analysis is often used as a method of choice to study the relationship between distinct compounds [38] as it does not involve expensive molecular experiments and may support valuable data on biological mechanisms.

Previously, we showed that in vitro tissue culture is moderated by copper $\left(\mathrm{Cu}^{2+}\right)$ and silver $\left(\mathrm{Ag}^{+}\right)$ions present in the regeneration medium [38], depending on the duration of culture. Mediation analysis [38] showed that sequence variation in barley plants obtained by tissue culture was due to the presence of $\mathrm{Cu}^{2+}$ and $\mathrm{Ag}^{+}$ions affecting CG sequences in different contexts, depending on the duration of tissue culture. Therefore, we hypothesized that sequence variation within other contexts might be induced by certain cellular compounds under the influence of abiotic stress, and this sequence variation may occur either throughout the duration of tissue culture or preferentially during specific intervals. To test this hypothesis, we investigated the putative origin of in vitro anther culture-induced sequence variation in barley regenerants using metAFLP markers, ATR-FTIR spectroscopy, and mediation analysis.

\section{Results}

Another culture of barley was performed in vitro under nine distinct treatments (M1-M9). Each treatment was conducted for a different duration and contained a different concentration of $\mathrm{Cu}^{2+}$ and $\mathrm{Ag}^{+}$ions. A total of 35 barley regenerants were obtained. No morphological differences were detected among the regenerants, and all regenerants were in the type of an anther tissue donor plant. DNA isolated from fresh leaves of a donor and regenerated DH plants using a commercial kit yielded intact samples without detectable impurities.

Genotyping of the isolated DNAs using the metAFLP approach allowed the identification of 407 markers shared by the donor plant and regenerants [25]. Quantitative metAFLP characteristics of the DNAs are listed in Table 1.

Table 1. Quantitative metAFLP characteristics and corresponding infrared spectroscopy data of barley regenerants derived by in vitro tissue culture under nine different trials (M1-M9).

\begin{tabular}{|c|c|c|c|c|c|c|c|c|c|}
\hline \multirow{2}{*}{$\begin{array}{c}\text { Sample } \\
\text { No. }\end{array}$} & \multirow[t]{2}{*}{ Trial } & \multicolumn{3}{|c|}{ Independent Variable ${ }^{1}$} & \multicolumn{3}{|c|}{ Mediator $^{1}$} & \multirow{2}{*}{$\begin{array}{c}\begin{array}{c}\text { Dependent } \\
\text { Variable }^{1}\end{array} \\
\text { SV }\end{array}$} & \multirow{2}{*}{$\begin{array}{c}\text { Moderator } \\
\text { Time } \\
\text { (Days) }\end{array}$} \\
\hline & & F710.690 & F1010.940 & $\begin{array}{l}\text { F710.690- } \\
\text { F1010.940 }\end{array}$ & DMV & CG_DMV & CHG_DMV & & \\
\hline 1 & M1 & 0.0012 & 0.0443 & 0.0455 & 1.6210 & 0.4636 & 1.1583 & 3.7058 & 21 \\
\hline 2 & M1 & 0.0021 & 0.0267 & 0.0288 & 1.3900 & 0.2325 & 1.1588 & 2.5488 & 21 \\
\hline 3 & M1 & 0.0018 & 0.0371 & 0.0389 & 1.3900 & 0.2315 & 1.1584 & 2.5479 & 21 \\
\hline 4 & M1 & 0.0014 & 0.0317 & 0.0332 & 1.3900 & 0.2315 & 1.1584 & 2.7794 & 21 \\
\hline 5 & M1 & 0.0011 & 0.0388 & 0.0399 & 1.6210 & 0.4630 & 1.1583 & 3.2423 & 21 \\
\hline 6 & M2 & 0.0010 & 0.0283 & 0.0293 & 1.6220 & 0.4637 & 1.1585 & 2.5481 & 28 \\
\hline 7 & M2 & 0.0015 & 0.0287 & 0.0302 & 1.6220 & 0.4650 & 1.1584 & 2.3171 & 28 \\
\hline 8 & M2 & 0.0018 & 0.0322 & 0.0339 & 1.3900 & 0.4640 & 0.9268 & 2.5482 & 28 \\
\hline 9 & M3 & 0.0014 & 0.0274 & 0.0288 & 1.3900 & 0.4640 & 0.9268 & 2.5482 & 35 \\
\hline 10 & M3 & 0.0014 & 0.0264 & 0.0279 & 1.6210 & 0.4636 & 1.1583 & 3.7058 & 35 \\
\hline 11 & M3 & 0.0008 & 0.0454 & 0.0461 & 1.6210 & 0.4637 & 1.1584 & 3.9377 & 35 \\
\hline 12 & M3 & 0.0018 & 0.0263 & 0.0281 & 1.3900 & 0.4640 & 0.9268 & 2.5482 & 35 \\
\hline 13 & M3 & 0.0019 & 0.0255 & 0.0275 & 1.3830 & 0.4616 & 0.9224 & 4.3802 & 35 \\
\hline 14 & M4 & 0.0011 & 0.0282 & 0.0293 & 1.3900 & 0.4640 & 0.9268 & 2.5482 & 28 \\
\hline 15 & M4 & 0.0013 & 0.0325 & 0.0338 & 1.3900 & 0.4640 & 0.9268 & 2.3166 & 28 \\
\hline 16 & M5 & 0.0010 & 0.0329 & 0.0339 & 1.3900 & 0.4637 & 0.9268 & 2.5482 & 35 \\
\hline 17 & M5 & 0.0009 & 0.0484 & 0.0493 & 1.3900 & 0.4630 & 0.9266 & 3.7055 & 35 \\
\hline 18 & M5 & 0.0009 & 0.0483 & 0.0491 & 1.6220 & 0.6952 & 0.9271 & 3.4748 & 35 \\
\hline
\end{tabular}


Table 1. Cont.

\begin{tabular}{|c|c|c|c|c|c|c|c|c|c|}
\hline \multirow{2}{*}{$\begin{array}{c}\text { Sample } \\
\text { No. }\end{array}$} & \multirow[t]{2}{*}{ Trial } & \multicolumn{3}{|c|}{ Independent Variable ${ }^{1}$} & \multicolumn{3}{|c|}{ Mediator $^{1}$} & \multirow{2}{*}{$\begin{array}{c}\text { Dependent } \\
\text { Variable }^{1}\end{array}$} & \multirow{2}{*}{$\begin{array}{c}\text { Moderator } \\
\begin{array}{c}\text { Time } \\
\text { (Days) }\end{array}\end{array}$} \\
\hline & & F710.690 & F1010.940 & $\begin{array}{l}\text { F710.690- } \\
\text { F1010.940 }\end{array}$ & DMV & CG_DMV & CHG_DMV & & \\
\hline 19 & M5 & 0.0018 & 0.0294 & 0.0312 & 1.8530 & 0.6954 & 1.1582 & 3.7057 & 35 \\
\hline 20 & M6 & 0.0011 & 0.0353 & 0.0364 & 0.9270 & 0.0000 & 0.9271 & 2.5487 & 21 \\
\hline 21 & M6 & 0.0013 & 0.0343 & 0.0356 & 1.3900 & 0.4640 & 0.9268 & 2.5482 & 21 \\
\hline 22 & M6 & 0.0016 & 0.0238 & 0.0254 & 0.9270 & 0.0000 & 0.9268 & 2.5484 & 21 \\
\hline 23 & M6 & 0.0018 & 0.0311 & 0.0329 & 1.1580 & 0.2323 & 0.9268 & 2.5483 & 21 \\
\hline 24 & M6 & 0.0015 & 0.0331 & 0.0346 & 1.1580 & 0.2315 & 0.9271 & 2.3167 & 21 \\
\hline 25 & M7 & 0.0014 & 0.0268 & 0.0283 & 1.8530 & 0.6944 & 1.1581 & 4.6315 & 35 \\
\hline 26 & M7 & 0.0009 & 0.0482 & 0.0492 & 1.6210 & 0.4630 & 1.1584 & 2.5478 & 35 \\
\hline 27 & M7 & 0.0010 & 0.0373 & 0.0383 & 1.3900 & 0.4630 & 0.9266 & 3.9370 & 35 \\
\hline 28 & M8 & 0.0009 & 0.0440 & 0.0449 & 0.0000 & 0.0000 & 0.0000 & 13.5169 & 21 \\
\hline 29 & M8 & 0.0004 & 0.0533 & 0.0537 & 0.0000 & 0.0000 & 0.0000 & 13.5170 & 21 \\
\hline 30 & M8 & 0.0014 & 0.0426 & 0.0440 & 0.0000 & 0.0000 & 0.0000 & 14.0089 & 21 \\
\hline 31 & M9 & 0.0013 & 0.0441 & 0.0454 & 2.0840 & 0.9267 & 1.1582 & 4.4006 & 28 \\
\hline 32 & M9 & 0.0015 & 0.0361 & 0.0377 & 1.1580 & 0.2320 & 0.9268 & 2.7798 & 28 \\
\hline 33 & M9 & 0.0013 & 0.0388 & 0.0400 & 1.1580 & 0.2320 & 0.9268 & 2.7798 & 28 \\
\hline 34 & M9 & 0.0016 & 0.0335 & 0.0351 & 1.1580 & 0.2320 & 0.9268 & 2.5486 & 28 \\
\hline 35 & M9 & 0.0019 & 0.0223 & 0.0243 & 2.0940 & 0.9320 & 1.1651 & 3.4931 & 28 \\
\hline
\end{tabular}

${ }^{1}$ DMV, demethylation; CG_DMV, demethylation of the CG context; CHG_DMV, demethylation of the CHG context; SV, sequence variation; F710.690, area under the spectral range from 710 to $690 \mathrm{~cm}^{-1}$; F1010.940, area under the spectral range from 1010 to $940 \mathrm{~cm}^{-1}$; F710.690-F1010.940, combination of F710.690 and F1010.940.

\subsection{ATR-FTIR Spectroscopy}

ATR-FTIR spectroscopy was carried out to investigate the major biochemical features of the leaves of barley regenerants in a fast and straightforward manner. Figure 1A summarizes the variability in infrared data between all treatments. The spectra showed typical features of plants (Figure 1A, inset), with several usually complex broad peaks. Bands representing asymmetric and symmetric methylene $\left(\mathrm{CH}_{2}\right)$ stretching vibrations were located at 2925 and $2848 \mathrm{~cm}^{-1}$, respectively, while the amide I band was centered at $1646 \mathrm{~cm}^{-1}$. In turn, the fingerprint region was characterized by two dominant peaks: one at $1397 \mathrm{~cm}^{-1}$, putatively assigned to the symmetric stretching vibrations of $\mathrm{COO}^{-}, \mathrm{CH}_{2}$ scissor, and $\mathrm{CH}$ bending $[39,40]$, and the other at $1058 \mathrm{~cm}^{-1}$, assigned to the $\mathrm{C}-\mathrm{O}, \mathrm{C}-\mathrm{O}-\mathrm{C}$ stretch, and ring vibrations, attributed mainly to polysaccharides [41,42]. The spectral range between 1200 and $600 \mathrm{~cm}^{-1}$, which was the focus of the present study, is depicted in Figure 1A. The local peak at $1153 \mathrm{~cm}^{-1}$ was assigned mostly to C-O-C asymmetric stretch vibrations, which are characteristic of various cell wall polysaccharides and therefore are not distinctive. The local peak at $1104 \mathrm{~cm}^{-1}$ representing C-O, C-O-C stretch, and ring vibrations is attributed mostly to cellulose [42,43]. To resolve the broad complex band centered at $1058 \mathrm{~cm}^{-1}$, we performed Gaussian deconvolution of the wavenumber range going from 1200 to $600 \mathrm{~cm}^{-1}$, achieving a very close fit to the original contour. The component peaks are presented in Figure 1B. The band at $1069 \mathrm{~cm}^{-1}$ was assigned mostly to $\mathrm{C}-\mathrm{O}$ and $\mathrm{C}-\mathrm{C}$ stretching vibrations of $\beta-(1 \rightarrow 3,1 \rightarrow 4)$ glucan [44], whereas the band at $1036 \mathrm{~cm}^{-1}$ was attributed to the C-O-C skeletal vibration of the polysaccharide ring of both cellulose and $\beta$-glucan [42]. Two small peaks were also generated at 991 and $960 \mathrm{~cm}^{-1}$, which seemed to contribute to the shape of the band shoulder; the former peak putatively reflects the $\beta$-glycosidic linkage, whereas the latter peak does not seem to be related to cell wall polysaccharides. The band at $960 \mathrm{~cm}^{-1}$ was attributed to $C-O$ and $C-C$ stretching in deoxyribose [45]. 

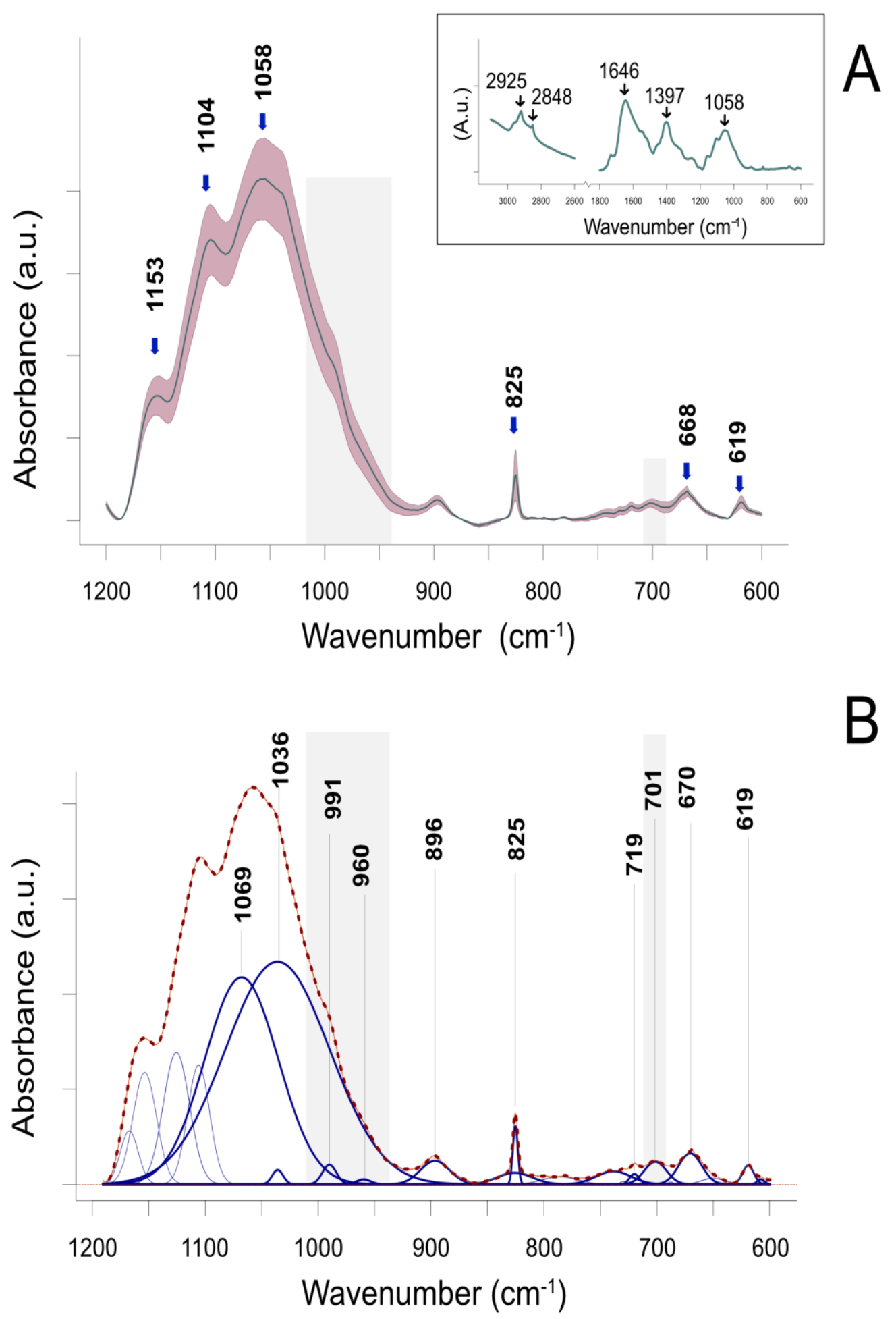

Figure 1. Attenuated Total Reflectance Fourier Transform Infrared (ATR-FTIR) spectrum of the leaves of barley plants regenerated by an in vitro anther culture. (A) ATR-FTIR spectra of the region between 1200 and $600 \mathrm{~cm}^{-1}$. The most prominent peaks are marked. The inset presents an extended range of the spectrum between 3100 and $600 \mathrm{~cm}^{-1}$. Data represent mean \pm standard deviation (SD). (B) Numerical (Gaussian) deconvolution of overlapping peaks. Data represent the sum of fitted curves (dashed line) closely overlapping the experimental data (solid red line). The centered frequencies of major resolved peaks are shown in blue. Regions shaded in gray represent spectral regions relevant to mediation analysis. 
The band at $896 \mathrm{~cm}^{-1}$ was assigned to $\beta$-glycosidic (C1-H) deformation [42]. A narrow, moderately intense peak at $825 \mathrm{~cm}^{-1}$ was probably caused by phenolic compounds containing a specifically substituted benzene ring; however, this peak was not considered essential in the present study. The resolved peak in the low-frequency region showed compounds at 719, 710, and $670 \mathrm{~cm}^{-1}$ [46]. Two bands at 701 and $670 \mathrm{~cm}^{-1}$ typically represent, in the case of cell wall material, $\mathrm{H}$-bonded O-H out-of-plane bending vibrations of cellulose $[47,48]$. However, these bands may be associated with vibrations unrelated to cell wall compounds, e.g., C-S stretching vibrations present in thiols or other compounds with C-S-C bonds [49-51].

\subsection{Mediation Analysis}

The analysis consisted of a series of regression mediation analyses that aimed to establish whether the DNA demethylation affecting CHG contexts (CHG_DMV) was a mediator in the relationship among F710.690, F1010.940, and F710.690-F1010.940 variables and sequence variation (SV). We have also tested the model of relationships between F710.690-F1010.940 and SV mediated by CHG_DMV and moderated by the time of in vitro tissue cultures.

The F710.690 mediation on sequence variation through CHG_DMV (mediator) was assumed to be insignificant based on indirect and partial indirect effects (not shown). Based on the complete standardized indirect effect, the mediation was nearly significant (Table 2). Moreover, based on the casual mediation approach [52] coefficient relating F710.690 and SV (path c) was significant, coefficient relating F710.690 and CHG_DMV (a) was significant. Furthermore, the CHG_DMV (mediator) was related to the SV (DV) when both F710.690 and CHG_DMV are predictors of the dependent variable $\left(c^{\prime}\right)$, the coefficient relating the F710.690 to the SV (c) was larger (in absolute value) than the coefficient relating the F710.690 to the SV in the regression model with both the F710.690 and the CHG_DMV $\left(c^{\prime}\right)$ predicting the dependent variable and indicating mediation. There were significant mediation effects of F1010.940 and F710.690-F1010.940 (Figure 2) as independent variables (IDs) on sequence variation through CHG_DMV (mediator). Table 2 shows the outcomes of simple mediation analyses from IDs to SV assessing the indirect effects of CHG_DMV (indicated by a 95\% confidence interval). All indirect effects except for the first model were positive. Mediation analysis showed that F1010.940 ATR-FTIR spectrum was a predictor of mediation, based on the indirect effect (IE) bootstrap value. Similarly, the indirect effect of the F710.690-F1010.940 variable on independent SV variables via the CHG_DMV (mediator) was significantly different from zero. The significance of mediations was assessed based on the Goodman test (F710.690: $Z=2.07, p=0.04$; F1010.940: $Z=2.47, p=0.01$; F710.690-F1010.940-: $Z=2.45, p=0.01$ ). The mediator variable's value accounted for (VAF) $84.5,71.4$, and $71 \%$ of the variance when the F710.690, F1010.940, and F710.690-F1010.940 variables were used respectively.

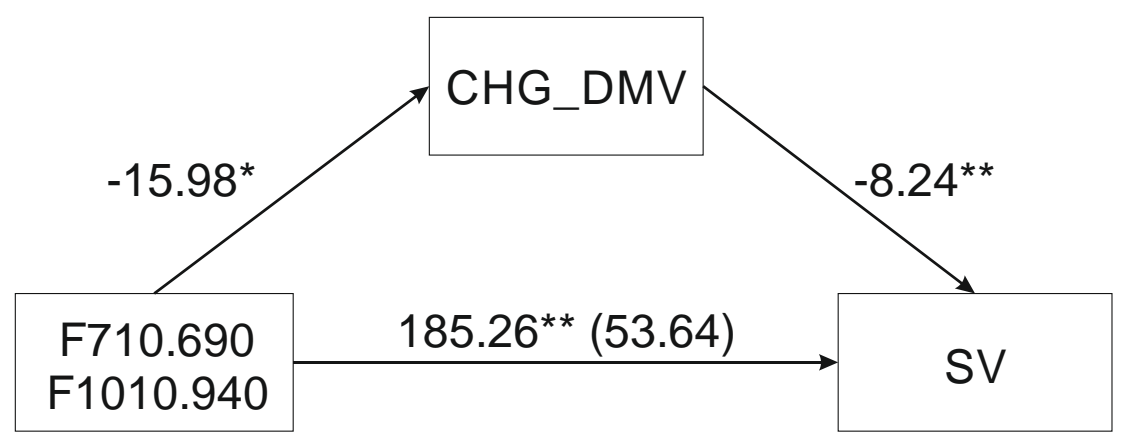

Figure 2. Mediation analysis of compounds associated with infrared spectral regions of 710-690 and $1010-940 \mathrm{~cm}^{-1}$ to demonstrate their effect on sequence variation (SV) via the demethylation of the CHG sequence context (CHG_DMV). ${ }^{*} p<0.05,{ }^{* *} p<0.01$ 
Table 2. Outcomes of mediation analyses from F710.690, F1010.940, and F710.690-F1010.940 to sequence variation assessing indirect effects. The unstandardized coefficients are given and explained in the table.

\begin{tabular}{|c|c|c|c|c|c|c|c|c|}
\hline \multirow[t]{2}{*}{ Model } & \multicolumn{6}{|c|}{ Effects } & \multicolumn{2}{|c|}{$95 \%$ CI } \\
\hline & $R^{2}$ & $c^{\prime}$ & $a$ & $b$ & $c$ & IE & $\mathbf{L}$ & $\mathbf{U}$ \\
\hline $\begin{array}{c}\text { F710.690- > } \\
\text { CHG_DMV- > SV }\end{array}$ & 0.79 & -436.37 & $274.82 *$ & $-8.59 * * *$ & $-2797.49 *$ & $-0.299^{\dagger}$ & $-0.56^{\dagger}$ & $0.06^{+}$ \\
\hline $\begin{array}{c}\text { F1010.940- > } \\
\text { CHG_DMV- > SV }\end{array}$ & 0.80 & 51.35 & $-15.57^{*}$ & $-8.24^{* * *}$ & $179.63 * *$ & 128.28 & 0.18 & 286.98 \\
\hline $\begin{array}{c}\text { F710.690-F1010.940- > } \\
\text { CHG_DMV- > SV }\end{array}$ & 0.80 & 53.64 & $-15.98 *$ & $-8.24^{* * *}$ & $185.26^{* * *}$ & 131.62 & 0.18 & 298.27 \\
\hline
\end{tabular}

F710.690, F1010.940, and F710.690-F1010.940 are the ATR-FTIR; CHG_DMV (mediator) states for DNA demethylation of the CHG contexts evaluated by metAFLP approach; SV is sequence variation also evaluated by the metAFLP approach and shared among anther culture derived regenerants of barley; $c^{\prime}=$ direct effect of predictor (IDs) on outcome (SV) while controlling for the mediator (CHG_DMV); $a=$ effect of the predictor (ID) on the mediator $($ CHG_DMV); $b=$ effect of the mediator (CHG_DMV) on the outcome (SV); $c=$ total effect focal predictor (F710.690, F1010.940, and F710.690-F1010.690) on the outcome (SV); IE = indirect effect of predictor (ID) on outcome (SV) through the mediator (CHG_DMV); $R^{2}$ - the amount of variance explained by the model; ${ }^{*} p<0.05,{ }^{* *} p<0.01$; ${ }^{* * *} p<0.001 ; \mathrm{L}$ and $\mathrm{U}$ are lower and upper values of $95 \%$ confidence interval $(\mathrm{CI}){ }^{+}{ }^{+}-$complete standardized indirect effect (C IE).

When the analysis tested relationship between F710.690-F1010.940 and SV mediated by CHG_DMV and moderated by the time of in vitro tissue cultures (Table 3) the model (Figure 3) was significant $(F(4,30)=66.25, p<0.0001)$ and explained $90 \%$ of the variance. The interaction between F710.690-F1010.940 and time as well as between CHG_DMV and time was significant based on bootstrap confidence intervals, indicating that mediation was moderated by time. Test of the highest order of unconditional interaction between F710.690-F1010.940 and time $\left(F(1,31)=9.89, R^{2}\right.$ chang $=0.1848$, $p<0.01)$ as well as between CHG_DMV and SV $\left(\mathrm{F}(1,30)=28.32, R_{\text {chang }}^{2}=0.096, p<0.0001\right)$ were also significant and explained $18.48 \%$ and $9.6 \%$ of variance, respectively. Johnson-Neuman's statistics indicated that moderation of F710.690-F1010.940 by time was significant through 30 days (Figure 4), and CHG_DMV through 28 days of in vitro tissue culture (Figure 5; data not shown). The indirect effect of moderated mediation was significant through 21 days of in vitro culture (Table 3 ). The indirect and direct effects of the moderated mediation calculated as $\beta a \times \beta b$ and $\beta a \times\left(\beta b+c^{\prime}\right)$ equaled 2804.153 and 2844.715 , respectively. Thus, the VAF values of the mediator variables accounted for $98.57 \%$ of the variance. The significance of the moderated mediator was also confirmed by the Goodman test $(Z=3.29, p<0.001)$.

Table 3. The outcomes (unstandardized regression coefficients) of mediation analyses from F710.690-F1010.940 to SV assessing the indirect effects of CHG_DMV (indicated by 95\% confidence interval) moderated by the time of in vitro tissue culture. For further explanation, see Table 2.

\begin{tabular}{|c|c|c|c|c|}
\hline Model: Moderated Mediation & $B$ & $S E$ & $95 \%$ CI L & $95 \%$ CI U \\
\hline$c^{\prime}$ & 40.5613 & 25.167 & -10.8377 & 91.9603 \\
\hline$a$ & $-94.5994^{* * *}$ & 25.8835 & -147.3903 & -41.8085 \\
\hline Time (moderator) & $-0.0887 *$ & 0.0335 & -0.1571 & -0.0204 \\
\hline Moderation: F710.690-F1010.940 × Time & $2.7594^{* *}$ & 0.8776 & 0.9696 & 4.5493 \\
\hline$b$ & $-29.6424^{* * * *}$ & 4.0666 & -37.9477 & -21.3371 \\
\hline Time (moderator) & $-0.9608 * * * *$ & 0.1848 & -1.3382 & -0.5834 \\
\hline Moderation: CHG_DMV $\times$ Time & $0.9633^{* * * *}$ & 0.181 & 0.5936 & 1.333 \\
\hline$c$ & 40.5613 & 25.167 & -10.8377 & 91.9603 \\
\hline \multicolumn{5}{|c|}{ Conditional indirect effect of F710.690-F1010.940 on SV (F710.690-F1010.940 -> CHG_DMV -> SV) } \\
\hline Time & $B$ & $S E$ & $\mathrm{~L}$ & $\mathrm{U}$ \\
\hline 21 & 344.9937 & 154.151 & 9.9749 & 633.6907 \\
\hline 28 & 46.2799 & 114.4689 & -7.6518 & 113.7094 \\
\hline 35 & 8.0692 & 53.3305 & -43.0736 & 72.1826 \\
\hline
\end{tabular}




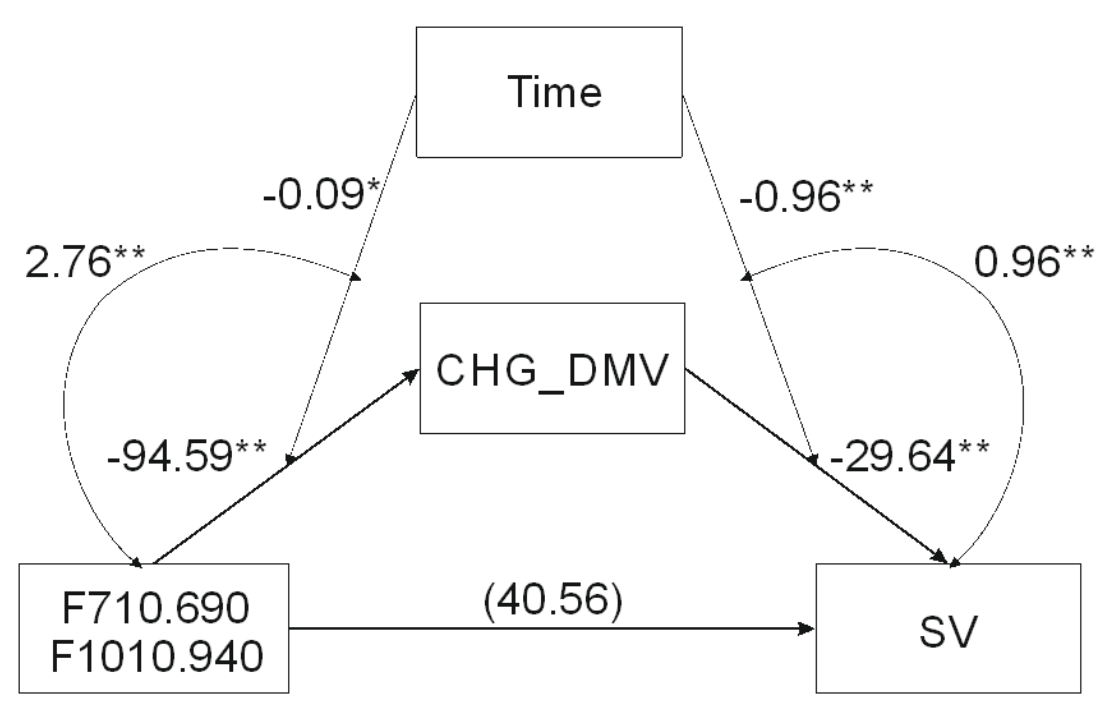

Figure 3. Mediation analysis of the compounds associated with infrared spectral regions of 710-690 and $1010-940 \mathrm{~cm}^{-1}$ to demonstrate their effect on sequence variation (SV) via demethylation of the CHG sequence context (CHG_DMV) moderated by time of tissue culture. ${ }^{*} p<0.05,{ }^{* *} p<0.01$.

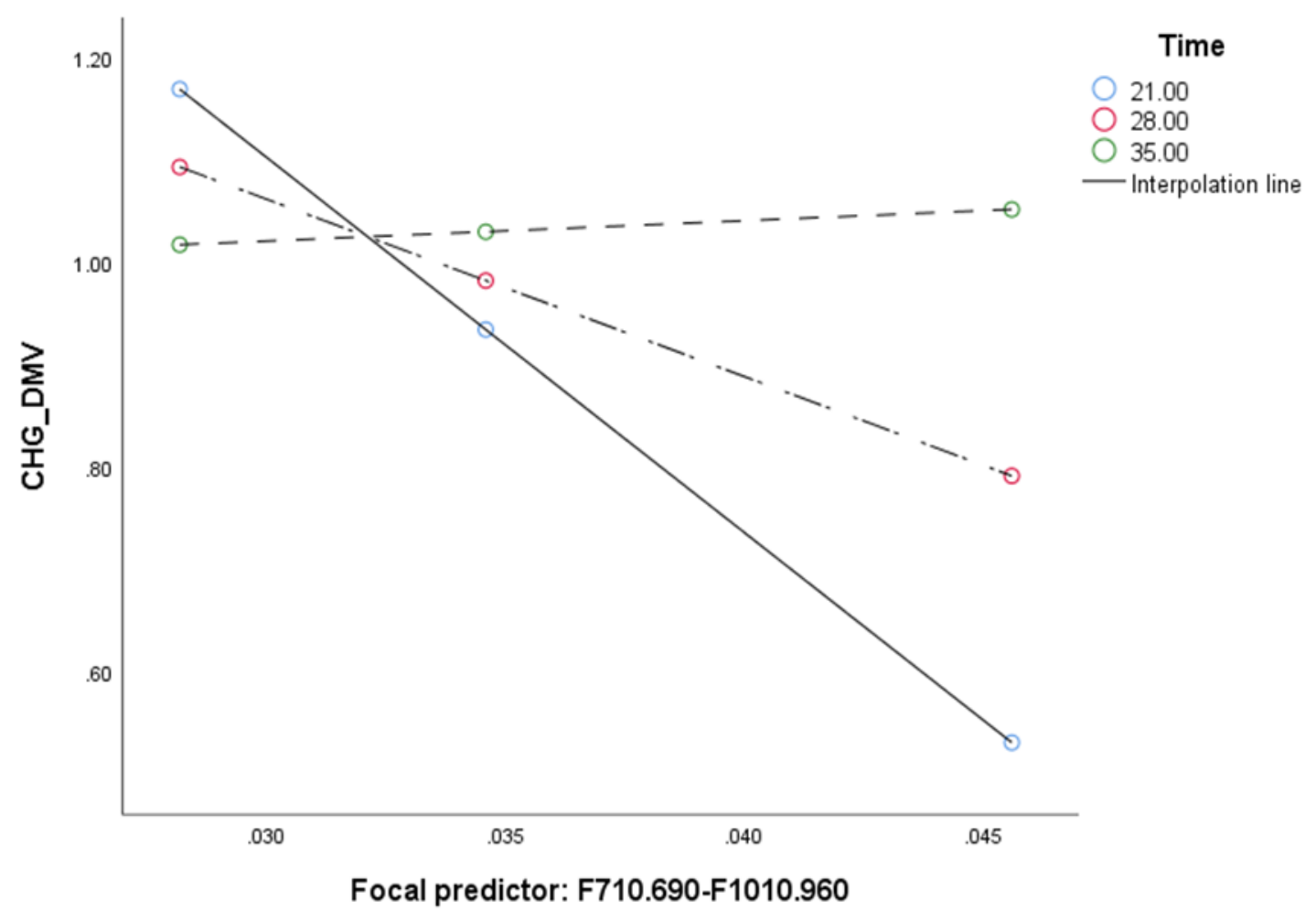

Figure 4. Conditional effect of the integrated absorbance area for regions $710-690$ and $1010-940 \mathrm{~cm}^{-1}$ (F710.690-F1010.940; predictor) under different durations of in vitro anther culture. 


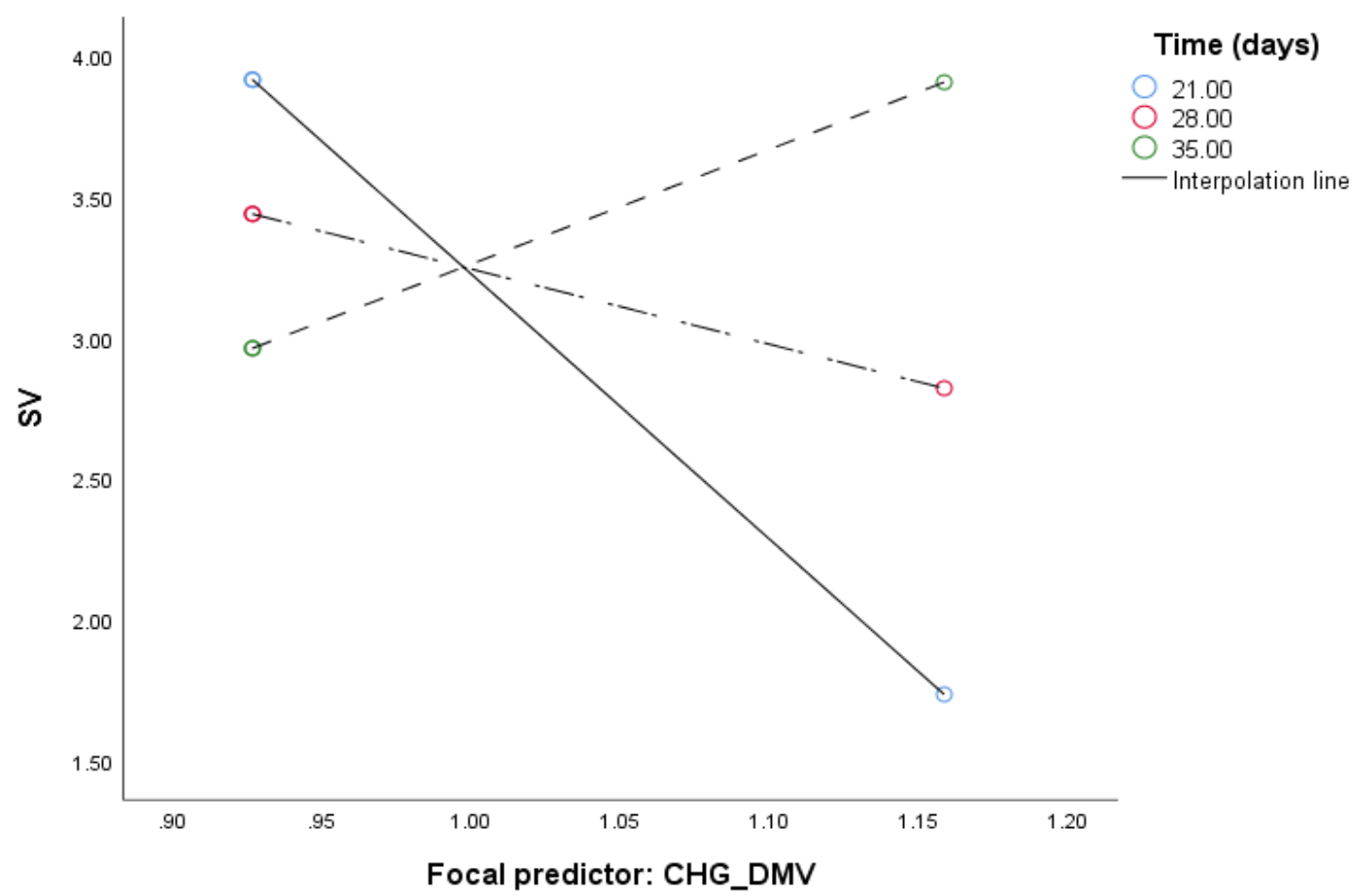

Figure 5. Conditional effect of demethylation of the CHG sequence context (CHG_DMV; predictor) under different durations of in vitro anther culture.

\section{Discussion}

To identify compounds that function as predictors in mediation analysis and explain the role of CHG_DMV in SV induced by in vitro tissue culture, we searched the biochemical profiles of leaves of barley plants exposed to variable growth conditions. We used ATR-FTIR spectroscopy to perform a comprehensive analysis of all major compounds present in barley leaves.

We decided to scan the entire mid-infrared spectrum to identify regions that potentially contributed to SV in plants regenerated by an in vitro anther culture. We predicted that this approach would allow us to verify the putative involvement of some vital biochemical pathways, including the methionine cycle [53] and its crucial compound S-adenosyl-L-methionine (SAM), in DNA methylation [54], which could contribute to SV [19]. Moreover, we suspected that compounds indicative of stress caused by in vitro culture, such as lipids [55], polyamines [56], and polysaccharides [57], might also affect DNA methylation.

Mediation analysis of the fragmented ATR-FTIR spectrum demonstrated that the wavenumber ranges 710-690 and 1010-940 $\mathrm{cm}^{-1}$ contributed significantly to performance of the statistical model if the integrated absorbances were treated as independent variables. When the two wavenumber ranges were combined into a single variable, the mediation was also significant, explaining as much as $71 \%$ of the variance. The VAF value was $<80 \%$, which clearly indicates that factors other than the moderator (CHG_DMV) would need to be incorporated into the model to fully explain SV induced by an in vitro anther culture. Previously, we found that the process of green plant regeneration was moderated by the presence of $\mathrm{Cu}^{2+}$ and $\mathrm{Ag}^{+}$ions in the medium, and depended on the time duration of the in vitro anther culture [58] (under review). Acquisition of plants via in vitro cultures can occur from explants by direct organogenesis or embryogenesis without previously formed callus $[59,60]$ or vicariously, when new shoots or embryos occurred on already formed callus (indirect organogenesis or embryogenesis) [61]. It is being suggested that under tissue culture conditions direct embryogenesis may proceed an indirect one. Thus, the role of time could be related to a moment when plant regeneration via indirect exceeds direct embryogenesis what might be linked to the utilization of $\beta$-glucans as a source of glucose under darkness [62]. Moreover, it was also demonstrated by us [38] that time was influential in the case of 
mediation between DNA demethylation of the CG sites and SV due to the presence of copper and silver ions in the medium. In this study, the time duration of in vitro culture was also a significant moderator. When these elements were incorporated into the model of moderated mediation, the VAF value increased to nearly $100 \%$, indicating that most of the essential factors were included in the model.

The $710-690 \mathrm{~cm}^{-1}$ band region is putatively associated with cellulose, whereas another band at approximately $665 \mathrm{~cm}^{-1}$ was also detected in the spectra of the examined material $[47,48]$. However, mediation analysis did not show a significant effect of the $665 \mathrm{~cm}^{-1}$ band, possibly because of the presence of cellulose in dissimilar forms and/or at different crystallinity levels, generating separate peaks. This contradiction may result from diverse patterns of intermolecular bonds and high sensitivity of the $\mathrm{O}-\mathrm{H}$ out-of-plane bending vibrations due to hydrogen bonding. Variation in the position of the peak attributed to cellulose, independent of the hydrogen bonding pattern and crystallinity level, has been reported previously $[47,48]$. The band region at $700 \mathrm{~cm}^{-1}$ may be associated with a more amorphic fraction of cellulose compared with that at $665 \mathrm{~cm}^{-1}$, and consequently only this fraction may be relevant for mediation analysis. Abiotic stresses during the regeneration process may be more influential on the amorphic fraction of cellulose than on the crystalline fraction. It is possible that stress due to the supply of $\mathrm{Cu}^{2+}$ and $\mathrm{Ag}^{+}$ions in the regeneration medium affected the status of cellulose primarily in a relatively more amorphic phase. In Miscanthus giganteum, a slight shift in the cellulose peak in this region of frequency has been observed as a result of mild chilling stress [63], which was associated with the formation of a more compact cellulose structure. The band at $700 \mathrm{~cm}^{-1}$ may be assigned not only to cellulose but also to the C-S stretching vibrations, which may be attributed to thiol or thioester functional groups. In the context of the apparent involvement of spectral data in the methylation process, an indication of SAM as a compound associated with this spectral region seems to be the most rational. The C-S stretch vibrations in the spectral region displayed a relatively strong signal, and the integrated absorbance may well explain the observed band even at a reasonably low concentration of the compound. Concerning the $710-690 \mathrm{~cm}^{-1}$ band region it should be stressed that mediation was not significant based on the indirect effect and nearly significant based on the completely unstandardized indirect effect. We tend to think that such a result is explained by a relatively small sample size rather than by a lack of mediation. The notion is supported by the fact that the compounds reflecting the $710-690 \mathrm{~cm}^{-1}$ spectrum region are documented in processes that may affect sequence variation.

Other spectra that acted as predictors in the mediation model included absorbances between 1010 and $940 \mathrm{~cm}^{-1}$. This spectral range constitutes a shoulder of intricate broadband, with a maximum at $1058 \mathrm{~cm}^{-1}$. The deconvolution of the band region generated two main components (located at 1069 and $1036 \mathrm{~cm}^{-1}$ ) and two much smaller peaks (at 991 and $960 \mathrm{~cm}^{-1}$ ), which could modulate the data associated with the F1010.940 variable. The broad peak with a maximum at $1058 \mathrm{~cm}^{-1}$ is greatly influenced by cellulose and hemicellulose [42]. In the hemicellulose fraction, $\beta$-glucans seemed to have the most substantial effect as signals, as pectins and other putative polysaccharides did not show clear specific peaks.

Since the contribution of $\beta$-glucans to the band region is marked, a similarly essential effect may be attributed to $\beta$-glucans in the $1010-940 \mathrm{~cm}^{-1}$ region. Therefore, both $\beta$-glucans and cellulose may contribute to mediation, and variability in the proportion of contribution between these two compounds may affect the model in mediation analysis.

The ATR-FTIR analysis of the 710-690 and 1010-940 $\mathrm{cm}^{-1}$ spectrum ranges suggests that these regions are associated with both cellulose and $\beta$-glucans, but the assignment of the 710-690 bands to cellulose was much more apparent than to $\beta$-glucans. Despite that the $710-690 \mathrm{~cm}^{-1}$ band is very weak, we are convinced that it reflects biological differentiation, due to both plant individual variability and the applied treatments. The technical repetitions (data not shown) were almost identical and did not infer observed data. We also exclude the randomness effect because the used spectrometer provided the spectra with the signal-to-noise ratio above 35,000:1. The absorbance in the $1010-940 \mathrm{~cm}^{-1}$ range showed an equal contribution of $\beta$-glucans and cellulose, although it was difficult to split the share. 
Thus, both $\beta$-glucans and cellulose can be considered as mediators, but the variability in the glucan content may be crucial for the model.

At a first glance, the role of $\beta$-glucans as a putative predictor of mediation seems suspicious. However, studies on cell wall signaling suggest that mitochondria and the cell wall cooperate to mediate stress responses [64]. Stresses can also affect the rate of respiratory electron transport, and mitochondria act as hubs for signaling to other cellular organelles [65]. $\beta$-glucans are a major component of the cell wall [66]. In vitro anther cultures are maintained in the dark [25]. Under such conditions, $\beta$-glucans are a source of metabolizable glucose [67]. Glucose from the cell wall in the form of $(1,3 ; 1,4)$ - $\beta$-glucans is mobilized quicker than glucose from starch (which is not available in tissue culture carried out in the dark). The process of $\beta$-glucan depolymerization requires only two enzymes: $(1,3 ; 1,4)-\beta$-glucan endohydrolase and the exo-acting $\beta$-glucan glucohydrolase [68], biosynthesis of lipids [69] that may act as signaling compounds [70,71] affecting gene expression [72,73]. Interestingly, $\beta$-1,3-linked D-glucose in the cell wall also protects plants from external stresses [74]. Other pathways linked to glycolysis and the tricarboxylic acid cycle (TCA) include the methionine cycle and ethylene biosynthesis pathway.

It is known that the ethylene biosynthesis pathway involving SAM [75-77] contributes to DNA methylation [78]. At low SAM concentration, the expression of genes involved in DNA repair and lipid and glucose metabolism is altered [79]. The decarboxylated form of SAM (dcAdoMet) is reported to block cytosine methylation [80]. Decarboxylated SAM may block DNA methylation by SAM and is also involved in polyamine synthesis [80]. Polyamines participate in the regulation of transcription, translation, cell growth, and apoptosis [80]. Thus, either changes in the expression of genes involved in DNA repair or the presence of mutations (such as $\mathrm{C} \rightarrow \mathrm{T}$ transitions) not recognized by DNA repair systems may act as a link between DNA methylation and SV induced by in vitro tissue culture [81]. Alternatively, SAM-e could be cleaved reductively by an iron-sulfur cluster-containing enzymes, producing an intermediate called 5'-deoxyadenosyl radical [82]. Such radicals may modify tRNA [83], causing rearrangements and other post-transcriptional modifications [84]. The $5^{\prime}$-deoxyadenosyl radical removes a hydrogen from proteins, RNA, or DNA (substrate) initiating a radical mechanism [80]. Radicals may induce DNA modifications leading to DNA mutations [85]. SAM is a key player in the methionine cycle, leading to ethylene biosynthesis. The level of ethylene is dependent on light conditions, and its regulation is dependent on enzymes participating in the ethylene pathway [86]. Since ethylene is a phytohormone that may affect gene expression and may depend on light conditions it may potentially contribute to SV. Thus, SAM and its derivatives may play a role in DNA mutations.

In the ATR-FTIR spectrum, the $1010-940 \mathrm{~cm}^{-1}$ range was linked to cellulose and $\beta$-glucans. Mediation analysis of the $1010-940 \mathrm{~cm}^{-1}$ range explained less variance, and mediation was not classified as full. This suggests that either cellulose is less critical for mediation and only influences the signal from $\beta$-glucans, or that cellulose participates in different mechanisms affecting SV. One possibility is that the level of cellulose affects $\mathrm{Cu}^{2+}$ and $\mathrm{Ag}^{+}$ions present in the regeneration medium and delivered to the cell via the cell wall. If this is true, then insufficient concentration of $\mathrm{Cu}^{2+}$ and $\mathrm{Ag}+$ ions in the medium should alter the biochemical pathways that require these ions. However, in this study, $\mathrm{Cu}^{2+}$ and $\mathrm{Ag}^{+}$ions were not incorporated in the model tested, as they were statistically insignificant (data not shown). The other possibility concerns the putative signaling pathway that links cellulose and mitochondria. Two pentatricopeptide repeat proteins, cell wall maintainer1 (cwm1) and cwm2, are involved in editing mitochondrial transcripts that encode subunits of the respiratory complex III, which is linked to the maintenance of cell wall integrity under stress and activation of retrograde mitochondrial signaling via ANAC017, a transcription factor involved in retrograde signaling to the nucleus upon mitochondrial dysfunction [87]. A complex hierarchy of transcription factors exists downstream of ANAC017, including ANAC and WRKY transcription factors associated with organellar signaling and senescence, and ethylene- and gibberellic acid-related transcription factors involved in stress responses [88].

Recently, a study showed that mitochondrial nicotinamide adenine dinucleotide (NAD) reduced oxidation links the TCA with methionine metabolism and nuclear DNA methylation [89]. 
The methionine cycle is a vital pathway in DNA methylation [90]. Studies show that 1-aminocyclopropane-1-carboxylic acid (ACC), the immediate precursor of ethylene, is involved in the regulation of the cell wall function and response to cell wall damage [91]. Thus, we believe that the signal from cellulose coincides with that from $\beta$-glucans using, at least to some extent, the same pathways that lead to DNA methylation.

Analysis of the moderated mediation showed that the model was highly influential, and inclusion of the time duration factor in the in vitro culture resulted in $98.57 \%$ VAF. Thus, the model explained nearly all variance. This is not surprising, as many cellular processes, including reprogramming, depend on time. The moderation effect of time was also observed when analyzing moderated moderation, where the moderation was conditional on the time of the entire in vitro culture period (21-30.1 days when relations between $\beta$-glucans and CHG_DMV were assumed, and until 28 days when CHG_DMV and SV were analyzed). Previously, we proposed that the moment when $\beta$-glucans become the predominant source of glucose in the cell coincides with the transition from direct to indirect embryogenesis [38]. However, in this study, the time of in vitro tissue culture was a non-significant moderator, possibly because of a different reason. It is possible that after 28 days of tissue culture, demethylation of the CHG context results in such a low level of methylated cytosines that the cell repair systems can easily cope with putative mutagenic modifications of cytosines. If this hypothesis is correct, the level of mutations after 28 days of tissue culture should be stabilized. Our results may also be interpreted in terms of the cell reprogramming process [12] affecting DNA demethylation change. Further studies are needed to confirm or reject this hypothesis.

Finally, it should be emphasized that the moderated mediation model presented in this study failed to explain the demethylation of CG sites, although the reason for this result is not apparent. However, we interpret the results in terms of how the process of DNA demethylation and its maintenance differ between the two sequence contexts [7,92]. Epigenetic mechanisms involved in demethylation of the CHG context [93] or maintenance of methylation [94] are most likely crucial here. We cannot exclude the possibility that differences between the two contexts are due to the fact that $\mathrm{CG}$ is predominant in euchromatic regions, whereas $\mathrm{CHG}$ and $\mathrm{CHH}$ sequences are more abundant in heterochromatic regions, and distinct mechanisms regulate the maintenance of the methylation of the two contexts [7].

\section{Materials and Methods}

\subsection{Plant Material}

The experiment was carried out on barley (Hordeum vulgare L.) of the NAD2 spring genotype obtained from Poznan Plant Breeding Ltd. (Nagradowice, Poland). The presented research was conducted on donor plants and their regenerants. The donor plants were the generative offspring of regenerants obtained by androgenesis in anther cultures. To obtain donor plants, seeds of the NAD2 genotype were sown and grown under controlled conditions: $16 \mathrm{~h}$ light $/ 8 \mathrm{~h}$ dark photoperiod, $16{ }^{\circ} \mathrm{C} / 12{ }^{\circ} \mathrm{C}$ during day/night, and approximately $190 \mu \mathrm{E} \mathrm{m}^{-2} \mathrm{~s}^{-1}$ light intensity using sodium lamps. Spikes from these plants were harvested when microspores were in the mid- to the late-uninucleate stage. To induce androgenesis, the spikes were kept in the dark at $4{ }^{\circ} \mathrm{C}$ for 21 days. After this time, the anthers were removed and placed on the N6L induction medium containing macro- and microelements [95] supplemented with $2 \mathrm{mg} \mathrm{L}^{-1}$ 2,4-dichlorophenoxyacetic acid, $0.5 \mathrm{mg} \mathrm{L}^{-1}$ naphthaleneacetic acid, and $0.5 \mathrm{mg} \mathrm{L}^{-1}$ kinetin. The anther plates prepared in this way were incubated in the dark at $26^{\circ} \mathrm{C}$. First androgenic structures were transferred onto regeneration medium K4NB [96] supplemented with $0.225 \mathrm{mg} \mathrm{L}^{-1}$ 6-benzylaminopurine. The incubation of the callus on the regeneration medium was carried out at temperature $26^{\circ} \mathrm{C}$ under the following photoperiod: $16 \mathrm{~h}$ light $/ 8 \mathrm{~h}$ dark. Appearing green regenerants were transferred to flasks on the N6I rooting medium [95] supplemented with $2 \mathrm{mg} \mathrm{L}^{-1}$ indole-3-acetic acid and then to pots and grown and greenhouses. The randomly chosen spikes of doubled haploid regenerants were self-pollinated, and finally, seeds were collected. Twenty four 
offspring obtained from doubled haploids were grown as donor plants to get regenerants for this experiment. The acquisition of regenerants for the present investigation was carried out according to the procedure described above for the donor plants. The difference was the use of nine variants of induction media, the base composition of which was the same. Still, the supplementation of copper and silver ions and the incubation time differed. Detailed supplementation of the induction media is included in Table 4. Each variant was treated as separate in vitro culture conditions and described as trial M1-M9. Trail M1, in which there are no Ag ions, and $\mathrm{Cu}$ ions are at the standard medium level, is a control sample, while trial M2-M9 are test samples. From the pool of 24 donor plants and their regenerants, it was possible to obtain regenerants in all the tested trials (M1-M9) for only one donor plant. This donor plant and its regenerants were taken for analysis. Hence, nine media with different concentrations of $\mathrm{CuSO}_{4}$ and $\mathrm{AgNO}_{3}$ and the different in vitro tissue culture duration were tested in terms of the influence of these conditions on the efficiency of green regenerant production and observed genetic/epigenetic variability and the biochemical compounds that may affect DNA methylation patterns and sequence variation.

Table 4. Concentrations of ions and number of days applied in trials (M1-M9).

\begin{tabular}{cccc}
\hline Trial & $\mathbf{C u}^{2+}(\mu \mathbf{M})$ & $\mathbf{A g}^{+}(\mu \mathbf{M})$ & Time (Days) \\
\hline M1 & 0.1 & 0 & 21 \\
M2 & 0.1 & 10 & 28 \\
M3 & 0.1 & 60 & 35 \\
M4 & 5 & 60 & 28 \\
M5 & 5 & 0 & 35 \\
M6 & 5 & 10 & 21 \\
M7 & 10 & 10 & 35 \\
M8 & 10 & 60 & 21 \\
M9 & 10 & 0 & 28 \\
\hline
\end{tabular}

\subsection{DNA Isolation and Analysis}

DNA was extracted from the fresh leaves of a donor plant and its regenerants using the DNeasy MiniPrep Kit (Qiagen, Hilden, Germany). MetAFLP was performed as described previously [25,28]. Quantitative metAFLP characteristics of demethylated CG and CHG sequences were evaluated as described previously [25].

To conduct ATR-FTIR spectroscopy, leaves were collected from barley regenerants and lyophilized using a speed-vac. The lyophilized leaves were homogenized to a fine powder using an agate mortar and pestle, and immediately used for ATR-FTIR analysis. Mid-infrared spectra were acquired using the iZ10 FTIR module of the Nicolet iN10 MX infrared microscope (Thermo Nicolet Corporation, Madison, WI, USA), equipped with a deuterated triglycine sulfate detector and potassium bromide (KBr) beam splitter. Measurements were recorded in the ATR mode using an ATR accessory (Smart Orbit, Thermo Fisher Scientific) equipped with a single-bounce diamond crystal. A pinch of the homogenized tissue was deposited on the crystal and pressurized against its surface using an attached pressure clamp. Sixty-four interferograms were collected and co-added before Fourier transformation at a wavelength ranging from 4000 to $400 \mathrm{~cm}^{-1}$ and at a resolution of $4 \mathrm{~cm}^{-1}$. The ATR crystal was carefully cleaned using ethanol before each measurement to remove any residual trace of the previous sample. The spectra were ATR, water vapor and baseline corrected using the OMNIC software (v. 9, Thermo Fischer Scientific). Spectra area normalization $\left(1800-900 \mathrm{~cm}^{-1}\right)$ and band integrated area calculations were performed using ChemoSpec [97], while spectra plots were generated using hyperSpec [98], the packages in R programming language [99]. To resolve overlapping peaks, deconvolution was performed using the Gaussian function and nonlinear least-squares fitting [100]. The whole spectrum was initially divided into sections of $10 \mathrm{~cm}^{-1}$, and each fragmented spectrum region was then subjected to a mediation analysis [101]. 


\subsection{Mediation Analysis}

The mediation analysis was performed in the SPSS software v. 26 (https://www.ibm.com/support/ pages/node/874712) using the A. F. Hayes Process v. 3.4 macro [101]. Model number 4 and 59 were exploited. Demethylation (DMV), demethylation of the CG contexts (CG_DMV), and demethylation of the CHG contexts (CHG_DMV) were used as putative mediators of sequence variation (SV). The infrared spectrum range (940-1010) was tested as the putative predictor of mediation. The mediation strength was measured using the variance accounted for (VAF) [102] value of the mediator (VAF $=$ indirect effect (IE)/total effect (TE)), indirect, partial, and complete standardized indirect effects of X on Y [103], and the Goodman test [104].

The minimum population size was calculated using the G-Power software [105]. Squared multiple correlation $\left(r^{2}\right)$ was set to 0.1 to calculate the effect size $\left(f^{2}\right)$ at $\alpha=0.05$ with three variables and a fixed value of power $(1-\beta$ error probability $=0.28)$.

Author Contributions: P.T.B. and R.O. conceived and designed the research. R.O. conducted the experiments. J.Z. conducted and designed the ATR-FTIR experiments. P.T.B. performed statistical analyzes. P.T.B., R.O., and J.Z. analyzed the generated data and wrote the manuscript. All authors have read and agreed to the published version of the manuscript.

Funding: This research was funded by the Ministry of Agriculture and Rural Development (Poland) grant no. HORhn-801-PB-22/15-18

Conflicts of Interest: The authors declare no conflict of interest.

\section{Abbreviations}

$\begin{array}{ll}5 \text { hmC } & \text { 5-hydroxymethylcytosine } \\ 5 \text { mC } & \text { 5-methylcytosine } \\ \text { ATR-FTIR } & \text { Attenuated Total Reflectance Fourier Transform Infrared } \\ \text { CG_DMV } & \text { demethylation of the CG contexts } \\ \text { CHG_DMV } & \text { demethylation of the CHG contexts } \\ \text { dcAdoMet } & \text { decarboxylated form of SAM } \\ \text { DMV } & \text { demethylation } \\ \text { IDM } & \text { increased DNA methylation complex } \\ \text { IF } & \text { indirect effect } \\ \text { metAFLP } & \text { methylation-sensitive Amplified Fragment Length Polymorphism } \\ \text { MMR } & \text { mismatch repair } \\ \text { NER } & \text { nucleotide excision repair } \\ \text { RdDM } & \text { RNA-directed DNA methylation } \\ \text { ROS1 } & \text { REPRESSOR OF SILENCING 1 } \\ \text { SAM } & \text { S-adenosyl-L-methionine, } \\ \text { SV } & \text { sequence variation } \\ \text { TCA } & \text { tricarboxylic acid cycle } \\ \text { TE } & \text { total effect } \\ \text { VAF } & \text { variance accounted for }\end{array}$

\section{References}

1. Naito, K.; Zhang, F.; Tsukiyama, T.; Saito, H.; Hancock, C.N.; Richardson, A.O.; Okumoto, Y.; Tanisaka, T.; Wessler, S.R. Unexpected consequences of a sudden and massive transposon amplification on rice gene expression. Nature 2009, 461, 1130. [CrossRef] [PubMed]

2. Tanurdzic, M.; Vaughn, M.W.; Jiang, H.; Lee, T.-J.; Slotkin, R.K.; Sosinski, B.; Thompson, W.F.; Doerge, R.W.; Martienssen, R.A. Epigenomic consequences of immortalized plant cell suspension culture. PLoS Biol. 2008, 6, e302. [CrossRef] [PubMed]

3. Birnbaum, K.D.; Roudier, F. Epigenetic memory and cell fate reprogramming in plants. Regeneration 2017, 4, 15-20. [CrossRef] [PubMed] 
4. Maki, H. Origins of Spontaneous Mutations: Specificity and Directionality of Base-Substitution, Frameshift, and Sequence-Substitution Mutageneses. Annu. Rev. Genet. 2002, 36, 279-303. [CrossRef]

5. Ito, S.; Shen, L.; Dai, Q.; Wu, S.C.; Collins, L.B.; Swenberg, J.A.; He, C.; Zhang, Y. Tet proteins can convert 5-methylcytosine to 5-formylcytosine and 5-carboxylcytosine. Science 2011, 333, 1300-1303. [CrossRef]

6. Fujii, S.; Akiyama, M.; Aoki, K.; Sugaya, Y.; Higuchi, K.; Hiraoka, M.; Miki, Y.; Saitoh, N.; Yoshiyama, K.; Ihara, K.; et al. DNA Replication Errors Produced by the Replicative Apparatus of Escherichia coli. J. Mol. Biol. 1999, 289, 835-850. [CrossRef]

7. Law, J.A.; Jacobsen, S.E. Establishing, maintaining and modifying DNA methylation patterns in plants and animals. Nat. Rev. Genet. 2010, 11, 204. [CrossRef]

8. Zhang, H.; Lang, Z.; Zhu, J.-K. Dynamics and function of DNA methylation in plants. Nat. Rev. Mol. Cell Biol. 2018, 19, 489-506. [CrossRef]

9. Slotkin, R.K.; Vaughn, M.; Borges, F.; Tanurdzic, M.; Becker, J.D.; Feijo, J.A.; Martienssen, R.A. Epigenetic reprogramming and small RNA silencing of transposable elements in pollen. Cell 2009, 136, 461-472. [CrossRef]

10. Zhang, H.; Zhu, J.K. Active DNA demethylation in plants and animals. Cold Spring Harb. Symp. Quant. Biol. 2012, 77, 161-173. [CrossRef]

11. Ooi, S.K.; Bestor, T.H. The colorful history of active DNA demethylation. Cell 2008, 133, 1145-1148. [CrossRef]

12. Li, Y.; Kumar, S.; Qian, W. Active DNA demethylation: Mechanism and role in plant development. Plant Cell Rep. 2018, 37, 77-85. [CrossRef] [PubMed]

13. Ortega-Galisteo, A.P.; Morales-Ruiz, T.; Ariza, R.R.; Roldán-Arjona, T. Arabidopsis DEMETER-LIKE proteins DML2 and DML3 are required for appropriate distribution of DNA methylation marks. Plant Mol. Biol. 2008, 67, 671-681. [CrossRef] [PubMed]

14. Gehring, M.; Bubb, K.L.; Henikoff, S. Extensive demethylation of repetitive elements during seed development underlies gene imprinting. Science 2009, 324, 1447-1451. [CrossRef] [PubMed]

15. Hsieh, T.F.; Ibarra, C.A.; Silva, P.; Zemach, A.; Eshed-Williams, L.; Fischer, R.L.; Zilberman, D. Genome-wide demethylation of Arabidopsis endosperm. Science 2009, 324, 1451-1454. [CrossRef]

16. Ausin, I.; Greenberg, M.V.C.; Simanshu, D.K.; Hale, C.J.; Vashisht, A.A.; Simon, S.A.; Lee, T.-F.; Feng, S.; Española, S.D.; Meyers, B.C.; et al. INVOLVED IN DE NOVO 2-containing complex involved in RNA-directed DNA methylation in Arabidopsis. Proc. Natl. Acad. Sci. USA 2012, 109, 8374-8381. [CrossRef]

17. He, X.-J.; Chen, T.; Zhu, J.-K. Regulation and function of DNA methylation in plants and animals. Cell Res. 2011, 21, 442-465. [CrossRef]

18. Globisch, D.; Münzel, M.; Müller, M.; Michalakis, S.; Wagner, M.; Koch, S.; Brückl, T.; Biel, M.; Carell, T. Tissue Distribution of 5-Hydroxymethylcytosine and Search for Active Demethylation Intermediates. PLoS ONE 2010, 5, e15367. [CrossRef]

19. Nabel, C.S.; Manning, S.A.; Kohli, R.M. The Curious Chemical Biology of Cytosine: Deamination, Methylation, and Oxidation as Modulators of Genomic Potential. ACS Chem. Biol. 2012, 7, 20-30. [CrossRef]

20. Wibowo, A.; Becker, C.; Marconi, G.; Durr, J.; Price, J.; Hagmann, J.; Papareddy, R.; Putra, H.; Kageyama, J.; Becker, J.; et al. Hyperosmotic stress memory in Arabidopsis is mediated by distinct epigenetically labile sites in the genome and is restricted in the male germline by DNA glycosylase activity. Elife 2016, 5, e13546. [CrossRef]

21. Yong-Villalobos, L.; González-Morales, S.I.; Wrobel, K.; Gutiérrez-Alanis, D.; Cervantes-Peréz, S.A.; Hayano-Kanashiro, C.; Oropeza-Aburto, A.; Cruz-Ramírez, A.; Martínez, O.; Herrera-Estrella, L. Methylome analysis reveals an important role for epigenetic changes in the regulation of the Arabidopsis response to phosphate starvation. Proc. Natl. Acad. Sci. USA 2015, 112, E7293-E7302. [CrossRef] [PubMed]

22. Ito, H.; Gaubert, H.; Bucher, E.; Mirouze, M.; Vaillant, I.; Paszkowski, J. An siRNA pathway prevents transgenerational retrotransposition in plants subjected to stress. Nature 2011, 472, 115-119. [CrossRef] [PubMed]

23. Coronel, C.J.; González, A.I.; Ruiz, M.L.; Polanco, C. Analysis of somaclonal variation in transgenic and regenerated plants of Arabidopsis thaliana using methylation related metAFLP and TMD markers. Plant Cell Rep. 2018, 37, 137-152. [CrossRef] [PubMed]

24. Machczyńska, J.; Zimny, J.; Bednarek, P. Tissue culture-induced genetic and epigenetic variation in triticale (× Triticosecale spp. Wittmack ex A. Camus 1927) regenerants. Plant Mol. Biol. 2015, 89, 279-292. [CrossRef] 
25. Orłowska, R.; Bednarek, P.T. Precise evaluation of tissue culture-induced variation during optimisation of in vitro regeneration regime in barley. Plant Mol. Biol. 2020. [CrossRef]

26. Polanco, C.; Ruiz, M.L. AFLP analysis of somaclonal variation in Arabidopsis thaliana regenerated plants. Plant Sci. 2002, 162, 817-824. [CrossRef]

27. Bednarek, P.T.; Orłowska, R. Plant tissue culture environment as a switch-key of (epi) genetic changes. Plant Cell Tissue Organ Cult. (PCTOC) 2020, 140, 245-257. [CrossRef]

28. Machczyńska, J.; Orłowska, R.; Zimny, J.; Bednarek, P.T. Extended metAFLP approach in studies of the tissue culture induced variation (TCIV) in case of triticale. Mol. Breed. 2014, 34, 845-854. [CrossRef]

29. Bednarek, P.T.; Orłowska, R.; Koebner, R.M.D.; Zimny, J. Quantification of the tissue-culture induced variation in barley (Hordeum vulgare L.). BMC Plant Biol. 2007, 7, 10. [CrossRef]

30. Kazarian, S.G.; Chan, K.L.A. ATR-FTIR spectroscopic imaging: Recent advances and applications to biological systems. Analyst 2013, 138, 1940-1951. [CrossRef]

31. Baker, M.J.; Trevisan, J.; Bassan, P.; Bhargava, R.; Butler, H.J.; Dorling, K.M.; Fielden, P.R.; Fogarty, S.W.; Fullwood, N.J.; Heys, K.A.; et al. Using Fourier transform IR spectroscopy to analyze biological materials. Nat. Protoc. 2014, 9, 1771-1791. [CrossRef] [PubMed]

32. Kumar, S.; Lahlali, R.; Liu, X.; Karunakaran, C. Infrared spectroscopy combined with imaging: A new developing analytical tool in health and plant science. Appl. Spectrosc. Rev. 2016, 51, 466-483. [CrossRef]

33. Gorgulu, S.T.; Dogan, M.; Severcan, F. The Characterization and Differentiation of Higher Plants by Fourier Transform Infrared Spectroscopy. Appl. Spectrosc. 2007, 61, 300-308. [CrossRef]

34. Lu, H.-F.; Shen, J.-B.; Lin, X.-Y.; Fu, J.-L. Relevance of Fourier transform infrared spectroscopy and leaf anatomy for species classification in Camellia (Theaceae). TAXON 2008, 57, 1274-1278. [CrossRef]

35. Alonso-Simón, A.; García-Angulo, P.; Mélida, H.; Encina, A.; Álvarez, J.M.; Acebes, J.L. The use of FTIR spectroscopy to monitor modifications in plant cell wall architecture caused by cellulose biosynthesis inhibitors. Plant Signal. Behav. 2011, 6, 1104-1110. [CrossRef]

36. Westworth, S.; Ashwath, N.; Cozzolino, D. Application of FTIR-ATR spectroscopy to detect salinity response in Beauty Leaf Tree (Calophyllum inophyllum L). Energy Procedia 2019, 160, 761-768. [CrossRef]

37. Willick, I.R.; Lahlali, R.; Vijayan, P.; Muir, D.; Karunakaran, C.; Tanino, K.K. Wheat flag leaf epicuticular wax morphology and composition in response to moderate drought stress are revealed by SEM, FTIR-ATR and synchrotron X-ray spectroscopy. Physiol. Plant. 2018, 162, 316-332. [CrossRef]

38. Bednarek, P.T.; Orłowska, R. CG Demethylation Leads to Sequence Mutations in an Anther Culture of Barley Due to the Presence of $\mathrm{Cu}, \mathrm{Ag}$ Ions in the Medium and Culture Time. Int. J. Mol. Sci. 2020, $21,4401$. [CrossRef]

39. Meyer, C.-L.; Juraniec, M.; Huguet, S.; Chaves-Rodriguez, E.; Salis, P.; Isaure, M.-P.; Goormaghtigh, E.; Verbruggen, N. Intraspecific variability of cadmium tolerance and accumulation, and cadmium-induced cell wall modifications in the metal hyperaccumulator Arabidopsis halleri. J. Exp. Bot. 2015, 66, 3215-3227. [CrossRef]

40. Stuart, B.H. Biological Applications of Infrared Spectroscopy; John WIley \& Sons, Ltd.: Chichester, UK, 1997.

41. Fan, M.; Dai, D.; Huang, B. Fourier Transform Infrared Spectroscopy for Natural Fibres. In Fourier Transform-Materials Analysis; Salih, S., Ed.; InTech: Rijeka, Croatia, 2012; pp. 45-68.

42. Kacuráková, M.; Capek, P.; Sasinková, V.; Wellner, N.; Ebringerová, A. FT-IR study of plant cell wall model compounds: Pectic polysaccharides and hemicelluloses. Carbohydr. Polym. 2000, 43, 195-203. [CrossRef]

43. Mathlouthi, M.; Koenig, J.L. Vibrational Spectra of Carbohydrates. In Advances in Carbohydrate Chemistry and Biochemistry; Tipson, R.S., Horton, D., Eds.; Academic Press: Cambridge, MA, USA, 1987; Volume 44, pp. 7-89.

44. Šandula, J.; Kogan, G.; Kačuráková, M.; Machová, E. Microbial (1 $\rightarrow 3)$ - $\beta$-d-glucans, their preparation, physico-chemical characterization and immunomodulatory activity. Carbohydr. Polym. 1999, 38, 247-253. [CrossRef]

45. Dovbeshko, G.I.; Gridina, N.Y.; Kruglova, E.B.; Pashchuk, O.P. FTIR spectroscopy studies of nucleic acid damage. Talanta 1997, 53, 233-246. [CrossRef]

46. Stuart, B.H. Infrared Spectroscopy: Fundamentals and Applications; John Wiley \& Sons: Chichester, UK, 2004.

47. Ilharco, L.M.; Garcia, A.R.; Lopes da Silva, J.; Vieira Ferreira, L.F. Infrared Approach to the Study of Adsorption on Cellulose: Influence of Cellulose Crystallinity on the Adsorption of Benzophenone. Langmuir 1997, 13, 4126-4132. [CrossRef] 
48. Kondo, T.; Sawatari, C. A Fourier transform infra-red spectroscopic analysis of the character of hydrogen bonds in amorphous cellulose. Polymer 1996, 37, 393-399. [CrossRef]

49. Cardoso, P.B.; Machado, T.O.; Feuser, P.E.; Sayer, C.; Meier, M.A.R.; Araújo, P.H.H. Biocompatible Polymeric Nanoparticles From Castor Oil Derivatives via Thiol-Ene Miniemulsion Polymerization. Eur. J. Lipid Sci. Technol. 2018, 120, 1700212. [CrossRef]

50. Hostetler, M.J.; Stokes, J.J.; Murray, R.W. Infrared Spectroscopy of Three-Dimensional Self-Assembled Monolayers: N-Alkanethiolate Monolayers on Gold Cluster Compounds. Langmuir 1996, 12, 3604-3612. [CrossRef]

51. Nyquist, R.A. Thiols, Sulfides and Disulfides, Alkanethiols, and Alkanedithiols (S-H stretching). In Interpreting Infrared, Raman, and Nuclear Magnetic Resonance Spectra; Academic Press: Cambridge, MA, USA, 2001; pp. 65-83.

52. MacKinnon, D.P.; Fairchild, A.J.; Fritz, M.S. Mediation Analysis. Annu. Rev. Psychol. 2007, 58, 593-614. [CrossRef]

53. Sauter, M.; Moffatt, B.; Saechao, M.C.; Hell, R.; Wirtz, M. Methionine salvage and S-adenosylmethionine: Essential links between sulfur, ethylene and polyamine biosynthesis. Biochem. J. 2013, 451, 145-154. [CrossRef]

54. Chiang, P.K.; Gordon, R.K.; Tai, J.; Zeng, G.C.; Doctor, B.P.; Pardhasaradhi, K.; McCann, P.P. S-Adenosylmethionine and methylation. FASEB J. 1996, 10, 471-480. [CrossRef]

55. Cui, X.-H.; Murthy, H.N.; Wu, C.-H.; Paek, K.-Y. Sucrose-induced osmotic stress affects biomass, metabolite, and antioxidant levels in root suspension cultures of Hypericum perforatum L. Plant Cell Tissue Organ Cult. (PCTOC) 2010, 103, 7-14. [CrossRef]

56. Carone, S.B.; Santa-Catarina, C.; Silveira, V.; Floh, E.I.S. Polyamine patterns in haploid and diploid tobacco tissues and in vitro cultures. Braz. Arch. Biol. Technol. 2010, 53, 409-417. [CrossRef]

57. Bishimbayeva, N.; Murtazina, A.; McDougall, G. Influence of Phytohormones on Monosaccharide Composition of Polysaccharides from Wheat Suspension Culture. Eurasian Chem. Technol. J. 2017, 19, 237-321. [CrossRef]

58. Bednarek, P.T.; Orłowska, R. Time of in vitro anther culture may moderate action of copper and silver ions that affect the relationship between DNA methylation change and the yield of barley green regenerants. Plants 2020, 9, unpublished work.

59. Ganeshan, S.; Chodaparambil, S.V.; Båga, M.; Fowler, D.B.; Hucl, P.; Rossnagel, B.G.; Chibbar, R.N. In vitro regeneration of cereals based on multiple shoot induction from mature embryos in response to thidiazuron. Plant Cell Tissue Organ Cult. 2006, 85, 63-73. [CrossRef]

60. Miroshnichenko, D.; Chaban, I.; Chernobrovkina, M.; Dolgov, S. Protocol for efficient regulation of in vitro morphogenesis in einkorn (Triticum monococcum L.), a recalcitrant diploid wheat species. PLoS ONE 2017, 12, e0173533. [CrossRef]

61. Biesaga-Kościelniak, J.; Kościelniak, J.; Janeczko, A. The impact of zearalenone and thidiazuron on indirect plant regeneration of oilseed rape and wheat. Acta Physiol. Plant. 2010, 32, 1047-1053. [CrossRef]

62. Burton, R.A.; Fincher, G.B. $(1,3 ; 1,4)-\beta-D-G l u c a n s$ in Cell Walls of the Poaceae, Lower Plants, and Fungi: A Tale of Two Linkages. Mol. Plant 2009, 2, 873-882. [CrossRef]

63. Bilska-Kos, A.; Mytych, J.; Suski, S.; Magoń, J.; Ochodzki, P.; Zebrowski, J. Sucrose phosphate synthase (SPS), sucrose synthase (SUS) and their products in the leaves of Miscanthus $\times$ giganteus and Zea mays at low temperature. Planta 2020, 252, 23. [CrossRef]

64. Hofmann, N.R. A Functional Link between Mitochondria and the Cell Wall in Stress Responses. Plant Cell 2016, 28, 1996. [CrossRef]

65. Huang, S.; Van Aken, O.; Schwarzländer, M.; Belt, K.; Millar, A.H. The Roles of Mitochondrial Reactive Oxygen Species in Cellular Signaling and Stress Response in Plants. Plant Physiol. 2016, 171, 1551-1559. [CrossRef]

66. Bulone, V.; Schwerdt, J.G.; Fincher, G.B. Co-evolution of Enzymes Involved in Plant Cell Wall Metabolism in the Grasses. Front. Plant Sci. 2019, 10. [CrossRef] [PubMed]

67. Roulin, S.; Buchala, A.J.; Fincher, G.B. Induction of $(1 \rightarrow 3,1 \rightarrow 4)-\beta$-D-glucan hydrolases in leaves of dark-incubated barley seedlings. Planta 2002, 215, 51-59. [CrossRef] [PubMed] 
68. Hrmova, M.; Fincher, G.B. Dissecting the catalytic mechanism of a plant $\beta$-d-glucan glucohydrolase through structural biology using inhibitors and substrate analogues. Carbohydr. Res. 2007, 342, 1613-1623. [CrossRef] [PubMed]

69. Zhai, Z.; Liu, H.; Xu, C.; Shanklin, J. Sugar Potentiation of Fatty Acid and Triacylglycerol Accumulation. Plant Physiol. 2017, 175, 696-707. [CrossRef] [PubMed]

70. Funck, D.; Clauß, K.; Frommer, W.; Hellmann, H. The Arabidopsis CstF64-Like RSR1/ESP1 Protein Participates in Glucose Signaling and Flowering Time Control. Front. Plant Sci. 2012, 3, 80. [CrossRef]

71. Price, J.; Laxmi, A.; St Martin, S.K.; Jang, J.-C. Global transcription profiling reveals multiple sugar signal transduction mechanisms in Arabidopsis. Plant Cell 2004, 16, 2128-2150. [CrossRef]

72. Jang, J.C.; Sheen, J. Sugar sensing in higher plants. Plant Cell 1994, 6, 1665-1679. [CrossRef]

73. Pego, J.V.; Kortstee, A.J.; Huijser, C.; Smeekens, S.C.M. Photosynthesis, sugars and the regulation of gene expression. J. Exp. Bot. 2000, 51, 407-416. [CrossRef]

74. Kesten, C.; Menna, A.; Sánchez-Rodríguez, C. Regulation of cellulose synthesis in response to stress. Curr. Opin. Plant Biol. 2017, 40, 106-113. [CrossRef]

75. Ding, W.; Smulan, L.J.; Hou, N.S.; Taubert, S.; Watts, J.L.; Walker, A.K. s-Adenosylmethionine Levels Govern Innate Immunity through Distinct Methylation-Dependent Pathways. Cell Metab. 2015, 22, $633-645$. [CrossRef]

76. Roje, S. S-Adenosyl-L-methionine: Beyond the universal methyl group donor. Phytochemistry 2006, 67, 1686-1698. [CrossRef] [PubMed]

77. Wang, K.L.-C.; Li, H.; Ecker, J.R. Ethylene Biosynthesis and Signaling Networks. Plant Cell 2002, 14, S131-S151. [CrossRef] [PubMed]

78. Zuo, J.; Wang, Y.; Zhu, B.; Luo, Y.; Wang, Q.; Gao, L. Comparative Analysis of DNA Methylation Reveals Specific Regulations on Ethylene Pathway in Tomato Fruit. Genes 2018, 9, 266. [CrossRef] [PubMed]

79. Yu, J. Obesity, Fatty Liver and Liver Cancer; Yu, J., Ed.; Springer: Singapore, 2018; p. 157.

80. Lu, S.C.; Mato, J.M. S-adenosylmethionine in Liver Health, Injury, and Cancer. Physiol. Rev. 2012, 92, 1515-1542. [CrossRef] [PubMed]

81. Modrich, P. DNA MISMATCH CORRECTION. Annu. Rev. Biochem. 1987, 56, 435-466. [CrossRef] [PubMed]

82. Booker, S.J.; Grove, T.L. Mechanistic and functional versatility of radical SAM enzymes. F1000 Biol. Rep. 2010, 2, 52. [CrossRef]

83. Zhang, B.; Arcinas, A.J.; Radle, M.I.; Silakov, A.; Booker, S.J.; Krebs, C. First Step in Catalysis of the Radical S-Adenosylmethionine Methylthiotransferase MiaB Yields an Intermediate with a [3Fe-4S]0-Like Auxiliary Cluster. J. Am. Chem. Soc. 2020, 142, 1911-1924. [CrossRef]

84. Broderick, J.B.; Duffus, B.R.; Duschene, K.S.; Shepard, E.M. Radical S-Adenosylmethionine Enzymes. Chem. Rev. 2014, 114, 4229-4317. [CrossRef]

85. Manova, V.; Gruszka, D. DNA damage and repair in plants-from models to crops. Front. Plant Sci. 2015, 6, 885. [CrossRef]

86. Harkey, A.F.; Yoon, G.M.; Seo, D.H.; DeLong, A.; Muday, G.K. Light Modulates Ethylene Synthesis, Signaling, and Downstream Transcriptional Networks to Control Plant Development. Front. Plant Sci. 2019, 10. [CrossRef]

87. Hu, Z.; Vanderhaeghen, R.; Cools, T.; Wang, Y.; De Clercq, I.; Leroux, O.; Nguyen, L.; Belt, K.; Millar, A.H.; Audenaert, D.; et al. Mitochondrial Defects Confer Tolerance against Cellulose Deficiency. Plant Cell 2016, 28, 2276-2290. [CrossRef] [PubMed]

88. Meng, X.; Li, L.; De Clercq, I.; Narsai, R.; Xu, Y.; Hartmann, A.; Lozano Claros, D.; Custovic, E.; Lewsey, M.G.; Whelan, J.; et al. ANAC017 coordinates organellar functions and stress responses by reprogramming retrograde signaling. Plant Physiol. 2019. [CrossRef]

89. Lozoya, O.A.; Martinez-Reyes, I.; Wang, T.; Grenet, D.; Bushel, P.; Li, J.; Chandel, N.; Woychik, R.P.; Santos, J.H. Mitochondrial nicotinamide adenine dinucleotide reduced (NADH) oxidation links the tricarboxylic acid (TCA) cycle with methionine metabolism and nuclear DNA methylation. PLoS Biol. 2018, 16, e2005707. [CrossRef] [PubMed]

90. Shen, W.; Gao, C.; Cueto, R.; Liu, L.; Fu, H.; Shao, Y.; Yang, W.Y.; Fang, P.; Choi, E.T.; Wu, Q.; et al. Homocysteine-methionine cycle is a metabolic sensor system controlling methylation-regulated pathological signaling. Redox Biol. 2020, 28, 101322. [CrossRef] [PubMed] 
91. Wolf, S.; Hématy, K.; Höfte, H. Growth Control and Cell Wall Signaling in Plants. Annu. Rev. Plant Biol. 2012, 63, 381-407. [CrossRef] [PubMed]

92. Parrilla-Doblas, J.T.; Roldán-Arjona, T.; Ariza, R.R.; Córdoba-Cañero, D. Active DNA Demethylation in Plants. Int. J. Mol. Sci. 2019, 20, 4683. [CrossRef] [PubMed]

93. Liu, R.; Lang, Z. The mechanism and function of active DNA demethylation in plants. J. Integr. Plant Biol. 2020, 62, 148-159. [CrossRef]

94. Bartels, A.; Han, Q.; Nair, P.; Stacey, L.; Gaynier, H.; Mosley, M.; Huang, Q.Q.; Pearson, J.K.; Hsieh, T.-F.; An, Y.-Q.C.; et al. Dynamic DNA Methylation in Plant Growth and Development. Int. J. Mol. Sci. 2018, 19, 2144. [CrossRef]

95. Chu, C.C. The N6 medium and its applications to anther culture of cereal crops. Proc. Symp. Plant Tissue Cult. Sci. Press Pekin. 1978, 43-50.

96. Kumlehn, J.; Serazetdinova, L.; Hensel, G.; Becker, D.; Loerz, H. Genetic transformation of barley (Hordeum vulgare L.) via infection of androgenetic pollen cultures with Agrobacterium tumefaciens. Plant Biotechnol. J. 2006, 4, 251-261. [CrossRef]

97. Hanson, B.A. ChemoSpec: Exploratory Chemometrics for Spectroscopy. R Package Version 4.4.97. 2017. Available online: https://CRAN.R-project.org/package=ChemoSpec (accessed on 12 December 2017).

98. Beleites, C.; Sergo, V. hyperspec: A Package to Handle Hyperspectral Data Sets in R. R Package Version 0.98-20161118. 2016. Available online: http://hyperspec.R-Forge.R-project.org/ (accessed on 19 November 2016).

99. R Core Team. R: A Language and Environment for Statistical Computing. R Foundation for Statistical Computing, Vienna, Austria. 2018. Available online: http://www.R-project.org/ (accessed on 20 December 2018).

100. Wojdyr, M. Fityk: A general-purpose peak fitting program. J. Appl. Crystallogr. 2010, 43, 1126-1128. [CrossRef]

101. Hayes, A.F. Introduction to Mediation, Moderation, and Conditional Process Analysis. In A Regression Bases Approach; A Division of Guilford Publications, Inc.: New York, NY, USA, 2018; p. 507.

102. Nitzl, C.; Roldan Jose, L.; Cepeda, G. Mediation analysis in partial least squares path modeling: Helping researchers discuss more sophisticated models. Ind. Manag. Data Syst. 2016, 116, 1849-1864. [CrossRef]

103. Preacher, K.J.; Kelley, K. Effect size measures for mediation models: Quantitative strategies for communicating indirect effects. Psychol. Methods 2011, 16, 93-115. [CrossRef] [PubMed]

104. Preacher, K.J.; Leonardelli, G.J. Calculation for the Sobel Test: An Interactive Calculation Tool for Mediation Tests. 2001. Available online: http://quantpsy.org/sobel/sobel.htm (accessed on 20 January 2009).

105. Faul, F.; Erdfelder, E.; Lang, A.-G.; Buchner, A. G*Power 3: A flexible statistical power analysis program for the social, behavioral, and biomedical sciences. Behav. Res. Methods 2007, 39, 175-191. [CrossRef] [PubMed] 